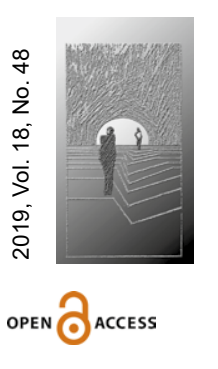

\title{
Bożena Sieradzka-Baziur
}

http://orcid.org/0000-0002-4214-7268

Akademia Ignatianum w Krakowie

Wydział Pedagogiczny

Instytutu Nauk o Wychowaniu

sieradzka4@gmail.com

DOI: 10.35765/HW.2019.1848.07

\section{Analiza pojęciowa wybranych manifestów pedagogicznych w ujęciu historycznym}

\section{STRESZCZENIE}

CEL NAUKOWY: Celem naukowym pracy jest pokazanie wyznaczników formalnych i semantyki wybranych polskich tekstów pedagogicznych z zakresu pedagogiki rodziny.

PROBLEM I METODY BADAWCZE: Problem postawiony w pracy dotyczy tego, jakie cechy gatunkowe mają teksty pedagogiczne odnoszące się do wychowywania dzieci, ich kształcenia i opieki nad nimi w rodzinie, oraz tego, jaki przekaz autor kieruje do założonych odbiorców. Metoda badawcza to analiza pojęciowa i porównawcza tekstów z zakresu pedagogiki stworzonych w różnych epokach historycznych (XVI w., XX w. i XXI w.).

PROCES WYWODU: W artykule zostały zaprezentowane wyznaczniki semantyczne i leksykalne pojęć „opieka, kształcenie i wychowanie” charakterystyczne dla pedagogiki rodziny.

WYNIKI ANALIZY NAUKOWEJ: Analiza wybranych tekstów pedagogicznych pokazuje, iż zagadnienia opieki, kształcenia i wychowania dzieci w rodzinie są nie tyle przedmiotem chłodnej refleksji, ile obiektem żarliwego namysłu i polemiki.

WNIOSKI, INNOWACJE, REKOMENDACJE: W celu dogłębnego zbadania cech gatunkowych i wyznaczników semantycznych oraz leksykalnych pojęć odnoszących się do opieki, wychowania i kształcenia w rodzinie konieczne jest stworzenie korpusu tekstowego wszystkich manifestów pedagogicznych adresowanych do rodziców i przeprowadzenie ich analizy pojęciowej.

$\rightarrow$ SŁOWA KLUCZOWE: PEDAGOGIKA RODZINY, HISTORIA WYCHOWANIA, MODEL WYCHOWANIA

\section{ABSTRACT}

A Conceptual Analysis of Selected Pedagogical Manifestos in Historical Terms

RESEARCH OBJECTIVE: The scientific goal of the work is to show the formal determinants and semantics of selected Polish pedagogical texts in the field of family pedagogy. 


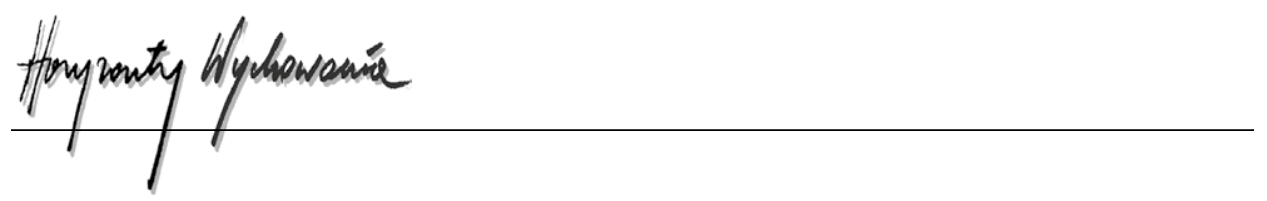

THE RESEARCH PROBLEM AND METHODS: The problem posed in the work relates to what genre features have pedagogical texts on the upbringing of children, their education and care in the family, and what message the author addresses to the intended recipients. The research method is a conceptual and comparative analysis of pedagogy texts created in various historical periods $\left(19^{\text {th }}, 20^{\text {th }}\right.$ and $\left.21^{\text {st }}\right)$.

THE PROCESS OF ARGUMENTATION: The article presents the semantic and lexical determinants of concepts care, education and upbringing characteristic of family pedagogy.

RESEARCH RESULTS: The analysis of selected pedagogical texts shows that issue of care, education and upbringing of children in the family are not the subject of cold reflection, but the object of ardent reflection and polemics.

CONCLUSIONS, INNOVATIONS, AND RECOMMENDATIONS: In order to thoroughly examine the genre features and semantic and lexical determinants of concepts related to family care, upbringing and education, it is necessary to create a text corpus of all pedagogical manifestos addressed to parents and conduct their conceptual analysis.

\section{$\rightarrow$ KEYWORDS: FAMILY PEDAGOGY, EDUCATION HISTORY, EDUCATION MODEL}

\section{Wprowadzenie}

Współcześnie pedagogika, jako dyscyplina naukowa usytuowana w obrębie nauk społecznych, stanowi gałąź wiedzy o wychowaniu, kształceniu i opiece. U jej początków znajduje się refleksja filozoficzna i religijna sięgająca swymi początkami czasów starożytnych. Na przestrzeni dziejów dociekania pedagogiczne miały charakter nie tylko filozoficzny i religijny, ale także publicystyczny czy - szerzej - literacki. Autorzy zajmujący się zagadnieniami pedagogicznymi wybierali rozmaite formy przekazu, należą do nich najczęściej teksty prozatorskie o różnej objętości. W niniejszym artykule przedmiotem rozważań staną się trzy wyraziste formalnie i semantycznie teksty dotyczące wychowania dzieci w rodzinie, opieki nad nimi i kształcenia, poprzez które nadawcy przekazują założonemu odbiorcy swój model pedagogicznego oddziaływania rodziców na dzieci.

W roku 1558 r. ukazała się pierwsza napisana po polsku książka z zakresu pedagogiki, zatytułowana Książki o wychowaniu dzieci barzo dobre, pożyteczne i potrzebne, z których rodzicy ku wychowaniu dzieci swych naukę dołożną wyczerpnąć mogą. Teraz nowo uczynione i z pilnością wyrobione autorstwa Erazma Glicznera (1535-1603), późniejszego teologa polemisty i tłumacza. Ten polski zabytek językowy zachował się od wieku XVI zaledwie w jednym egzemplarzu, przechowywanym w Bibliotece Zakładu Narodowego im. Ossolińskich (XVI 1116), i od tego czasu został wydany w całości tylko jeden raz (1876), nigdy nie zyskując popularności wśród czytelników. Traktat szesnastowiecznego autora zgodnie z ówczesną poetyką wykazuje silne zależności od literatury starożytnej i Biblii (Sieradzka-Baziur, 2018). 
Trzy i pół wieku później ukazał się manifest pedagogiczny Jak kochać dziecko. Dziecko w rodzinie Janusza Korczaka (1878?-1942). Ta jedna z najsłynniejszych monografii pedagogicznych została wydana najpierw w roku 1919, potem w 1920, a następnie (jako drugie wydanie) w roku 1929, i to właśnie wydanie jest podstawą analiz zaprezentowanych w tym artykule (por. też Sieradzka-Baziur, 2019a; 2019b). Dzieło Korczaka nie jest zwyczajnym poradnikiem, lecz monografią o niezwykłej, nieodkrytej jeszcze do końca głębi, tekstem człowieka, który pisze nie tylko o rozwoju fizycznym, psychicznym, emocjonalnym i społecznym dziecka, ale odnosi się także do jego indywidualności i duchowości. Dzieło wielkiego pedagoga jest pomyślane jako poradnik, więc w tekście są tylko nieliczne odwołania do prac naukowych.

Erazm Gliczner i Janusz Korczak to prekursorzy pedagogiki rodziny w naszym kraju. W swoich dziełach zaprezentowali oryginalne modele wychowania dziecka w rodzinie. Anna Błasiak (2010, s. 15) pisze, iż dociekania naukowe i badania nad rodziną mają swój początek w XIX w., a zostały zintensyfikowane w drugiej połowie wieku XX. Pedagogika rodziny rozwija się intensywnie w XXI w., przynosząc niezliczoną ilość opracowań naukowych. W tym nurcie badań i refleksji nad rodziną tworzone są również liczne teksty pedagogiczne, które mając charakter dyrektywny, służą pedagogizacji rodziców. W prezentowanym artykule przedmiotem analizy, obok wskazanych Książek o wychowaniu dzieci (...) oraz Jak kochać dziecko. Dziecko w rodzinie, jest poradnik Mikołaja Marceli pod prowokacyjnym tytułem Jak nie spieprzyć życia swojemu dziecku. Wszystko, co możesz zrobić, żeby edukacja miała sens, wydany w roku $2020^{1}$. Skupiając się głównie na zagadnieniach związanych z kształceniem dziecka w rodzinie i zarządzaniem edukacją dziecka przez rodzinę, autor odwołuje się m.in. do prac Johna Holta, Jespera Juula, Kena Robinsona, Yuvala Noaha Harari.

Wymienione powyżej teksty pedagogiczne są wyrazem poglądów autorów na temat tego, jaki model wychowania powinien panować w rodzinie, przy czym Gliczner i Marcela skupiają się głównie na zagadnieniach kształcenia dziecka w rodzinie - i w ścisłym związku z nią, zwracając uwagę na decydującą rolę rodziców w tym zakresie, natomiast Korczak podejmuje przede wszystkim zagadnienia związane z opieką nad dzieckiem w rodzinie i jego wychowaniem - a w mniejszym stopniu z kształceniem.

\section{Cel badań i metodologia przyjęta w pracy}

Celem podjętych badań jest pokazanie, jak w konkretnych warunkach historycznych dany autor podchodzi do kwestii wychowania dziecka w rodzinie, kształcenia go i sprawowania nad nim opieki. Metodologia przyjęta w pracy to analiza pojęciowa zawartości

\footnotetext{
${ }^{1}$ Współcześnie wyraz „spieprzyć” jest „słowem dla wielu osób wulgarnym”, por. Wielki słownik języka polskiego, red. P. Żmigrodzki, https://www.wsjp.pl/ (dostęp: 20.04.2020). Chwyt stylistyczny zastosowany przez Marcelę ma z pewnością charakter marketingowy, co w kontekście tematyki będącej przedmiotem rozważań autora zawartych w pracy (kształcenie dzieci i młodzieży) oceniam negatywnie.
} 


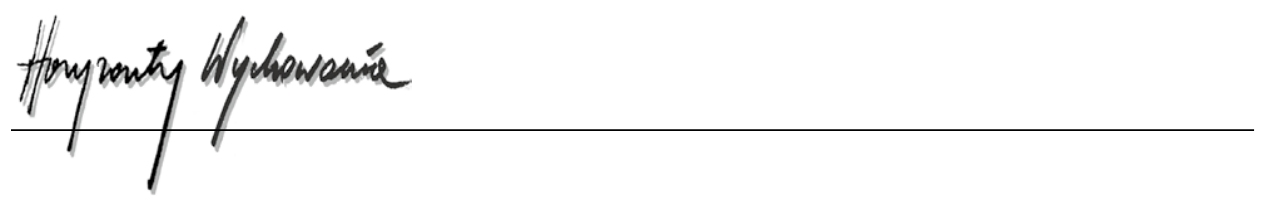

semantycznej wybranych tekstów pedagogicznych w ujęciu historycznym. Pojęcia stanowią reprezentację (odzwierciedlenie, odwzorowanie) obiektów w umyśle użytkownika (por. Bremer i Chuderski, 2011). Pojęć nie definiujemy, lecz wskazujemy ich wyznaczniki semantyczne i leksykalne. Zabieg badawczy określany przeze mnie mianem konceptualizacji strukturyzującej polega na zgromadzeniu w obrębie pojęć ich wyznaczników leksykalnych, czyli wyrazów, wyrażeń, konstrukcji wyrazowych określających to, co jest obiektem spostrzegania autora dzieła, jego myślenia i przekonań oraz emocji. Główne pojęcia charakterystyczne dla pedagogiki rodziny to: rodzina, opieka w rodzinie, kształcenie w rodzinie i wychowanie w rodzinie. One też będą głównym przedmiotem analiz w tym artykule.

\section{Ukształtowanie formalne analizowanych tekstów}

Wszystkie analizowane utwory to teksty prozatorskie o zbliżonej objętości - są to monografie liczące około 200 stron, podzielone na rozdziały. Ich prymarnymi adresatami są członkowie rodziny, przy czym szesnastowieczny autor Erazm Gliczner odbiorcą swego tekstu uczynił ojca, Janusz Korczak swój przekaz z początku XX w. kieruje głównie do matki, a współczesny twórca - Mikołaj Marcela - do obydwojga rodziców, co wynika zasadniczo ze specyfiki czasów, w których żyją autorzy. Dodatkowymi adresatami poradnika Marceli są nauczyciele i dyrektorzy szkół (por. s. 234).

Cechą charakterystyczną analizowanych tekstów pedagogicznych jest ich dialogiczność. Podmiot, wyrażający się w pierwszej osobie liczby pojedynczej (ja), w drugiej osobie liczby mnogiej (my) bądź bezosobowo (np. formy powinno się, należy etc.), zwraca się do założonych adresatów z najróżniejszymi radami, pouczeniami, wskazówkami, ostrzeżeniami, apelami etc. Cechą charakterystyczną monografii Korczaka jest to, że autor oddaje głos także dziecku i matce, którzy wypowiadają się w pierwszej osobie liczby pojedynczej. Podmiotem edukacji w czasach Glicznera są tylko synowie i o nich pisze twórca. Korczak i Marcela, zajmując się procesami pedagogicznymi w rodzinie, podmiotami czynią dzieci obojga płci i obydwaj ci autorzy zwracają uwagę na nierówne traktowanie chłopców i dziewcząt (por. Korczak, 1929, s. 138-140, 152-154; Marcela, 2020, s. 189-191). Każdą z analizowanych monografii określić można mianem manifestu bądź poradnika pedagogicznego, bowiem autorzy, tożsami z podmiotem mówiącym w tekście, w sposób jednoznaczny nadają im charakter programowy - są przeświadczeni o słuszności swoich poglądów na temat wychowania i z wielką pasją przekonują do wcielania ich w życie. Na uwagę zasługuje fakt, że teksty te, pisane z potrzeby serca, są żywymi, pełnymi emocji utworami, w których dominuje nie tylko funkcja impresywna, ale na równych prawach także ekspresywna, gdyż autorzy nasycili swoje teksty bezkompromisowymi i zhiperbolizowanymi hasłami o charakterze postulatywnym. Zabiegi stylistyczne wykorzystywane w celu przekonania adresatów do swoich racji to niejednokrotnie zaskakujące metafory, porównania, zdania wykrzyknikowe i wyrazy nacechowane emocjonalnie, wypowiedzi o charakterze żartobliwym, pytania retoryczne, konstrukcje charakterystyczne dla języka potocznego. 


\section{Struktura pojęciowa analizowanych tekstów}

Analiza pojęciowa zawartości semantycznej tekstów Glicznera, Korczaka i Marceli umożliwiła skupienie w obrębie określonej nazwy pojęcia jego wyznaczników semantycznych i leksykalnych. Semantyka analizowanych tekstów jest zogniskowana wokół pojęć rodzina, opieka w rodzinie, kształcenie w rodzinie i wychowanie w rodzinie.

\section{Rodzina}

Zawarte w analizowanych tekstach wykładniki leksykalne pojęcia „rodzina”, odnoszące się do członków rodziny, to w utworze Glicznera ociec (ojciec) i syn (osoby pierwszego planu); matka (osoba drugiego planu), a także córka; dziecko z nieprawego łoża, bękart. Korczak używa nazw takich jak matka, dziecko czyli syn lub córka (osoby pierwszego planu); ojciec (osoba drugiego planu), a także babcia, dziad (dziadzio), rodzeństwo, ciotka, wuj. U Marceli znajdujemy określenia matka, ojciec, syn, córka (osoby pierwszego planu); a także babcia, pradziadek. Gliczner prezentuje szesnastowieczną rodzinę drobnej szlachty polskiej, Korczak przedstawia polską rodzinę mieszczańską pierwszej połowy XX w., zaś Marcela w swoich opisach odwołuje się przede wszystkim do swojej własnej rodziny - inteligenckiej, z przełomu XX i XXI w., i innych współczesnych rodzin, w których wychowują się uczące się lub studiujące dzieci. Dane leksykalne wyekscerpowane z trzech analizowanych tekstów pokazują, które osoby współtworzą w analizowanym tekście rodzinę. Różnice dotyczą zarówno pierwszo-, jak i drugoplanowych i innych, tylko okazjonalnie się pojawiających w analizowanych przekazach, członków rodziny. Mimo że Gliczner i Korczak prowadzą narrację w pierwszej osobie liczby pojedynczej (ja) bądź mnogiej $(m y=j a)$, to w swoich poradnikach nie odnoszą się do wychowania, opieki i kształcenia dzieci w rodzinach swojego pochodzenia, natomiast Marcela prezentuje obszerny obraz własnej rodziny, wyrażając przekonanie, że rodzina, w której się wychował, jej sposób sprawowania opieki, procesy wychowawcze i kształceniowe zapewniły mu sukces w życiu. Jest to według niego rodzina wzorcowa.

\section{Opieka w rodzinie}

Zagadnienia opieki nad dzieckiem w rodzinie wiążą się głównie z zaspokajaniem jego potrzeb związanych z rozwojem fizycznym i psychicznym. Wykładniki semantyczne pojęcia „opieka w rodzinie” i dawniej, i dziś mieszczą w sobie działania dotyczące takich obszarów, jak: odżywianie i pielęgnacja dziecka, zapewnienie dziecku wystarczającej ilości snu i szerzej wypoczynku, wystarczającej ilości ruchu, a także ochrona przed zimnem czy gorącem, dbałość o bezpieczeństwo dziecka, starania dotyczące jego dobrostanu psychicznego, zapewnienie wystarczających warunków materialnych 


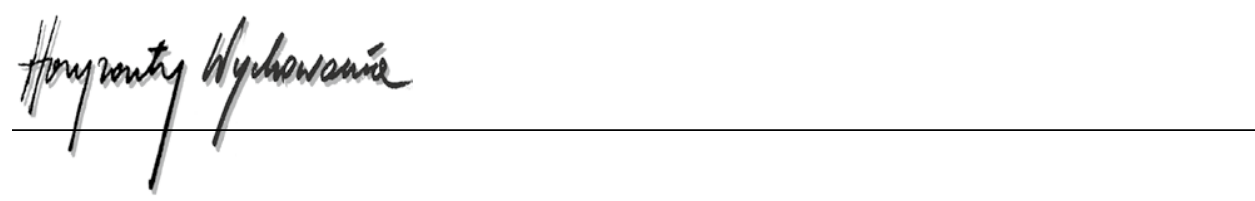

(mieszkanie etc.). W różnych epokach, regionach świata i rodzinach te uniwersalne potrzeby dziecka były i są zaspokajane w zróżnicowany sposób.

Wykładniki leksykalne pojęcia „opieka” zawarte w każdym z analizowanych tekstów odnoszą się do osób sprawujących opiekę, podopiecznych oraz czynności opiekuńczych. Szesnastowieczny autor poucza rodziców o tym, że powinni usilnie zabiegać o zdrowie i szczęście dzieci. Pedagog pisze, iż matka powinna sama karmić swoje dzieci piersią, a nie zatrudniać do tego mamki (najemnej matki). Autor zajmuje się też kwestią ubierania dzieci, nie rozpatruje jednak ubrań w kategoriach ochrony przed chłodem, ale podkreśla aspekt pedagogiczny związany z ich ubieraniem - kształcenie umysłu jest według niego ważniejsze aniżeli dbałość o wygląd zewnętrzny.

Korczak zajął się zagadnieniami opieki nad dzieckiem w szerokim zakresie i w swoim poradniku dał wyraz przemyśleniom m.in. na temat prokreacji, karmienia piersią oraz konieczności zapewnienia dzieciom wystarczającej ilości snu, zwracając ostro uwagę na błędy, jakie popełniają rodzice, por. np. „Zmuszanie dzieci, by spały, gdy im się spać nie chce, jest przestępstwem. Tablica, która głosi, kiedy ile godzin snu dziecku potrzeba, jest absurdem" (s. 84). Autor pisze też o takich zagadnieniach związanych z opieką, jak krzyk i płacz dziecka, i o postawach matek, które są rozczarowane swoimi dziećmi, gdyż oczekiwały tylko pozytywnych doświadczeń w kontaktach z nimi. Nie waha się określić takich zachowań mianem dziecinnego zadąsania i samolubnej goryczy (s. 21). Podkreśla, że dzieci mają prawo do dobrego samopoczucia, zwracając uwagę na to, że są one przez matki „przekarmiane, przegrzewane, chronione przed urojonem niebezpieczeństwem” (s. 72). Monografia Korczaka nie ma charakteru podręcznika pediatrii, gdyż nie znajdujemy w niej zbyt wielu medycznych ustaleń naukowych. Informacje na temat fizycznego rozwoju dziecka, podane językiem potocznym, poparte są rozważaniami, sentencjami lekarza i pedagoga, mającego duże doświadczenie w zakresie opieki nad dziećmi. Autor jest bezkompromisowy w ocenach negatywnych postaw opiekuńczych rodziców:

Są dzieci kapryśne, widziałem ich parę dziesiątków podczas godzin przyjęć lekarskich. Te dzieci wiedzą, czego chcą, ale tego im nie dadzą: im tchu brak, one się duszą pod ciężarem troskliwej opieki. Jeśli na ogół stosunek dzieci do dorosłych jest chłodny, te patologicznie kapryśne dzieci pogardzają i nienawidzą swego otoczenia. Nierozumną miłością można katować dzieci; prawo winno je wziąć pod opiekę (s. 112).

Mikołaj Marcela, pisząc o opiece nad dzieckiem w rodzinie, zauważa, że rodzice nie dbają wystarczająco o dobrostan psychiczny swoich dzieci, skupiając się przede wszystkim na ich wynikach w nauce. W jego książce znalazły się rady dotyczące tego, iż rodzice powinni zapewnić dzieciom czas na wypoczynek oraz zabawę i w większym niż dotąd zakresie dzielić się opieką nad dziećmi.

\section{Kształcenie w rodzinie}

Rodzina stanowi pierwszą instytucję edukacyjną, w której prowadzone są i moderowane zróżnicowane działania kształceniowe, przy czym w niektórych epokach i rodzinach 
zadania te były czy są realizowane w ograniczonym, a nawet szczątkowym stopniu, ale też w stopniu właściwym. Kształcenie może być również traktowane przez rodziców w sposób przesadny - jako najistotniejsze działanie związane z funkcjonowaniem dziecka. Działania edukacyjne dotyczą przede wszystkim rozwoju poznawczego wychowanków. Wykładniki semantyczne pojęcia „kształcenie w rodzinie” to, w zależności od epoki czy uwarunkowań rodzinnych, przekazywanie wiedzy z zasobów edukacyjnych członków rodziny oraz moderowanie działań kształceniowych, czyli np. pomoc w wyborze kierunku kształcenia w określonych szkołach i uczelniach wyższych, wsparcie wychowawcze i materialne związane z kształceniem się dziecka.

Wykładniki leksykalne pojęcia „kształcenie”, pojawiające się w analizowanych tekstach pedagogicznych, odnoszą się do podmiotów nauczania, osób prowadzących kształcenie, przedmiotów nauczania, miejsc prowadzenia edukacji. Gliczner, określając podmioty nauczania, używa takich nazw, jak np. uczeń, dyscypuł 'uczeń', żak, student. Pisząc o osobach prowadzących kształcenie, stosuje nazwy mistrz, nauczyciel, pedagog, preceptor. Przedmioty nauczania odnotowane w renesansowym poradniku to czytanie, pisanie; łacina; nauki wyzwolone. Edukacja w renesansie prowadzona była w szkołach, kolegiach, akademiach, ale też w domu ucznia czy na dworach (dworackie szkołowanie). Gliczner zagadnieniu kształcenia dzieci poświęca zasadniczą część swojego traktatu i stawia pytanie dotyczące tego, kiedy należy przystąpić do edukowania dziecka. Uważa, że dzieci powinny rozpocząć naukę wtedy, gdy zaczynają mówić. Wtedy należy zacząć uczyć je czytać i pisać. Podkreśla wyższość nauki szkolnej nad nauką rzemiosła i krytycznie odnosi się do praktyki polskiej instytucji wychowawczej, jaką była w owych czasach służba dworska dzieci i młodzieży. Autor wyraża pogląd, że rodzice powinni zapewnić dzieciom naukę w szkole, gdyż wpłynie to na ich uspołecznienie. Nauczyciel powinien być dobrym chrześcijaninem, ma być dobrze wykształcony i cechować się wysokim poziomem moralnym, a rodzice muszą mieć świadomość, że wykształcenie dzieci jest kosztowne - nie powinni żałować pieniędzy na ten cel.

W tekście Korczaka sporadycznie pojawiają się określenia związane z edukacją i należą do nich takie, jak nauczyciel, szkoła, powszechne nauczanie. Autor uważa, że dziecko powinno w życiu szukać swojej drogi i rodzic nie powinien mu narzucać tego, kim ma w przyszłości zostać. Korczak oddał głos dwu matkom - każda z nich jest zatroskana o przyszłość swojego dziecka: pierwsza, bo z braku środków finansowych musi oddać dziecko do terminu, gdzie będzie uczyło się rzemiosła, zamożniejsza ubolewa, że dziecko będzie musiało ciężko pracować w szkole (s. 72). Pedagog przyznaje dziecku prawo do zwyczajności, negując pogląd, że liczy się tylko to, co wybitne, bowiem

Dziecko nie jest biletem loteryjnym, na który ma paść wygrana portretu w sali posiedzeń magistratu czy biustu w przedsionku teatru. W każdem jest iskra własna, która może rozpalać ogniska szczęścia i prawdy, może w dziesiątym pokoleniu wybuchnie pożarem genjusza i spali własny ród, dając ludzkości światło nowego słońca (s. 71).

Tekst Marceli zawiera bogate słownictwo (w tym nacechowane) związane z systemem edukacji. W jego obrębie można wyróżnić np. nazwy podmiotów nauczania uczeń, 


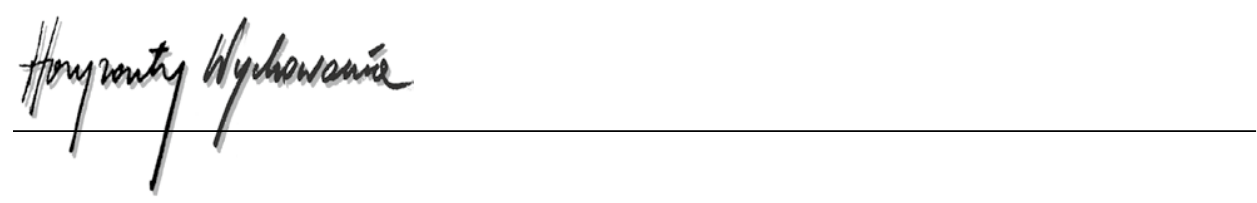

uczeń = więzień systemu oświaty (s. 269), student, nazwy osób prowadzących kształcenie: rodzice = pierwsi nauczyciele; nauczyciel, mistrz, mentor, funkcjonariusz systemu edukacji (s. 73, 75); nazwy modeli kształcenia i ich cechy. Marcela swoją książkę poświęcił głównie zagadnieniu kształcenia dzieci w rodzinie i dzięki rodzinie, zwracając m.in. uwagę na błędy, które popełniają pod tym względem rodzice. Stawiają swoim dzieciom zbyt wysokie wymagania odnoszące się do kształcenia, wypełniają im cały wolny czas zajęciami pozalekcyjnymi, a w rezultacie szkoła i nauka dominują życie młodych ludzi. Autor jest krytyczny wobec publicznej edukacji w Polsce i wyraża przekonanie, że szkoła przyszłości powinna funkcjonować bez ocen, podstawy programowej i sprawdzianów. Według autora, współczesna polska szkoła uczy „bierności, uległości i lęku przed porażką” (s. 9) i odbywa się w niej „upokarzająca zarówno dzieci, jak i nauczycieli «gra w naukę»” (s. 59), a system edukacji jest „nieludzki” (s. 78, por. też s. 256). Za takimi autorami, jak np. John Holt, Jesper Juul, Ken Robinson, Yuval Noah Harari, pokazuje, że współczesny model szkoły, oparty na modelu stworzonym w XIX w. w Prusach, nie sprawdza się w XXI w., stąd zmiany w systemach edukacji na świecie, np. w Finlandii. Autor omawia takie alternatywne modele kształcenia, jak edukacja demokratyczna, szkoły Montessori, edukacja waldorfska, stwierdzając, że polska szkoła powinna korzystać z tych wzorów, i zachęcając rodziców do tego, aby walczyli o zmianę aktualnego systemu edukacji w Polsce. Krytyczne, a niekiedy i napastliwe poglądy autora dotyczące współczesnej edukacji są zgodne z obiegowymi opiniami na ten temat w Polsce i w innych krajach. W celu ich zweryfikowania konieczne jest podjęcie szerokich badań oświatowych o charakterze zarówno ilościowym, jak i jakościowym, dotyczących współczesnej szkoły, sprawdzenie zgodności z rzeczywistością obiegowych sądów na temat sposobów przekazywania wiedzy i systemu oceniania dokonań wychowanków, funkcjonowania ucznia w szkole, współpracy pracowników szkoły z rodzicami - a wszystko to w celu stworzenia prawdziwego obrazu szkolnictwa w Polsce, wolnego od uproszczeń i pobieżnych ocen, oraz podjęcie ewentualnych koniecznych działań w celu poprawy funkcjonowania systemu edukacji.

\section{Wychowanie w rodzinie}

Wykładniki semantyczne pojęcia „wychowanie w rodzinie” odnoszą się do takich oddziaływań wychowawcy na wychowanka, które w zamierzeniu wychowawcy mają zapewnić rozwój osobie poddawanej temu procesowi. Wychowanie w rodzinie trwa od momentu narodzenia dziecka i bywa prowadzone aż do końca życia rodziców. Jego specyfika uwarunkowana jest przede wszystkim więzami emocjonalnymi między rodzicami a dziećmi. Działania wychowawcze dotyczą szczególnie rozwoju duchowego, moralnego i społecznego wychowanków.

Wyznaczniki leksykalne pojęcia „wychowanie” wyekscerpowane z analizowanych tekstów pedagogicznych określają głównie podmioty wychowania, osoby prowadzące wychowanie i style wychowania. 
Erazm Gliczner pisze, że obowiązek troski o wychowanie syna spoczywa na ojcu do końca jego życia. Powinien się on głównie troszczyć o rozwój duchowy wychowanka. Przestrzega rodziców przed „wielkim kochaniem a pieszczeniem” (s. 70), gdyż „miękkie a rozkoszne wychowanie sił żadnych, nie tylko w mocy ku członkom, ale też i ku rozumowi przydawać nie może" (s. 73). Zgodnie z poglądami panującymi w tym okresie Gliczner pisze, iż rodzice powinni dyscyplinować dzieci poprzez wymierzanie im kar cielesnych oraz przez surowe pouczenia. Ojcowie powinni służyć dzieciom radą w kwestii wyboru drogi życiowej (małżeństwa czy kapłaństwa). W traktacie uwidacznia się religijność Glicznera, który zawarł w nim różnorodne zwroty do Boga i dłuższe modlitwy. Swój manifest pedagogiczny kończy prośbą do Boga o to, aby inni kontynuowali to dzieło, które rozpoczął swoją pierwszą książką pedagogiczną napisaną po polsku.

Janusz Korczak, pisząc o zagadnieniach związanych z wychowaniem dzieci, formułuje w całym tekście wiele słynnych praw, które przysługują dzieciom, a wśród nich „prawo dziecka do śmierci; do dnia dzisiejszego; do tego, by było tem, czem jest; do wypowiadania swych myśli, czynnego udziału w naszych o niem rozważaniach i wyrokach" (por. Korczak, 1929). Pedagog żarliwie, w słowach pełnych pasji, na przestrzeni całego utworu postuluje prawo dziecka do wolności, pisząc, iż wychowanek jest „dzieckiem przymusu, niewoli, pańszczyzny” (s. 95), a wychowawcy zapominają, iż „winniśmy uczyć dziecko nie tylko cenić prawdę, ale i rozpoznawać kłamstwo, nie tylko kochać, ale też i nienawidzieć, nie tylko szanować, ale i pogardzać, nie tylko godzić się, ale i oburzać, nie tylko ulegać, ale i buntować się (s. 137). Autor przestrzega przed zgubnym wychowywaniem „wygodnego dziecka” (s. 18), spełniającego życzenia rodziców, dostosowującego się do ich oczekiwań, bo w przyszłości będzie ono „bezwolne wewnętrznie i niedołężne życiowo" (s. 68). Korczak pisze, iż dzieci wykonują specyficzną pracę określaną przez niego „przenikaniem” dorosłych, sprowadzającą się do uważnej analizy postaw wychowawców, którzy nie chcą tych działań wychowanków zauważać. Gdyby uświadomili sobie, jak wyraźnie widzą wychowankowie ich obłudę i śmieszność, wówczas musieliby się przyznać do tego, że nie są doskonali, albo do tej doskonałości dążyć (s. 96-97).

Mikołaj Marcela zachęca rodziców do tego, aby pozostawali ze swoimi dziećmi w autentycznym kontakcie, prowadzili z nimi dialog i obdarzali zaufaniem. Pisze o roli osobistego przykładu w wychowaniu dziecka, zwracając uwagę na potrzebę świętowania jego osiągnięć, uczenia go tego, jak pokonywać strach, obawy i negatywne myślenie. Sposobem na wyjaśnienie trudnych zagadnień jest, według autora, storytelling, gdyż dzięki „mocy opowiadania opuszczamy swoje «tu i teraz», i wraz z bohaterem odbywamy «podróż», z której powracamy już odmienieni” (s. 216). Rodzice powinni być przyjaciółmi swoich dzieci i jeśli to konieczne, brać je w obronę przed nauczycielami w szkole, dając w ten sposób wyraz swojej rodzicielskiej lojalności. Autor pomija zaostrzające się w ostatnich latach zjawisko deprecjonowania nauczycieli przez rodziców i ich niejednokrotnie roszczeniową postawę, co jest źródłem silnych napięć w szkole, wywierających negatywny wpływ na jej funkcjonowanie. 


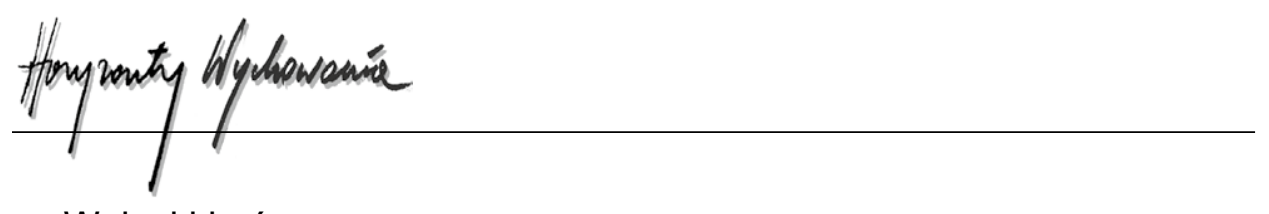

\section{Wnioski końcowe}

Analiza pojęciowa i porównawcza tekstów pedagogicznych Erazma Glicznera, Janusza Korczaka i Mikołaja Marceli tworzonych w różnych epokach historycznych pokazuje, iż zagadnienia opieki nad dziećmi w rodzinie, ich wychowania i kształcenia są nie tyle przedmiotem chłodnej refleksji, ile obiektem poważnego namysłu ich twórców oraz polemiki z obserwowaną rzeczywistością pedagogiczną. Każdy z autorów jest przekonany o przemożnym wpływie rodziców na dalsze losy dziecka. Podkreślając sprawczość rodziców w kwestii rozwoju wychowanka, skupiają się na głównych procesach pedagogicznych zachodzących w rodzinie, przyznając im różną rangę - w zależności od własnej wiedzy i kompetencji w tym zakresie, przyjętego światopoglądu i celu, jaki stawiali swoim poradnikom. W celu całościowego zbadania cech gatunkowych i wyznaczników leksykalnych pojęć charakterystycznych dla pedagogiki rodziny konieczne jest stworzenie korpusu tekstowego wszystkich poradników dla rodziców i przeprowadzenie ich analizy pojęciowej.

\section{BIBLIOGRAFIA}

Błasiak, A. (2010). Pedagogika rodziny w kręgu nauk o rodzinie i nauk pedagogicznych. W: A. Błasiak i E. Dąbrowska (red.), Wybrane zagadnienia pedagogiki rodziny. Kraków: Wyższa Szkoła Filozoficzno-Pedagogiczna „Ignatianum”, Wydawnictwo WAM, 15-23.

Bremer, J. i Chuderski, A. (red.) (2011). Pojęcia. Jak reprezentujemy i kategoryzujemy świat. Kraków: Universitas.

Erazma Glicznera Książki o wychowaniu dzieci (1876). Opracował W. Wisłocki. Kraków: Nakładem Księgarni D.E. Friedleina.

Gliczner, E. (1558). Książki o wychowaniu dzieci barzo dobre, pożyteczne i potrzebne, z których rodzicy ku wychowaniu dzieci swych naukę dołożną wyczerpnąć mogą. Teraz nowo uczynione i z pilnością wyrobione. W Krakowie drukowano przez Mateusza Siebeneichera Roku Pańskiego M.D.L. viii. Pozyskano z: Dolnośląska Biblioteka Cyfrowa, http://www.dbc.wroc.pl (dostęp: 22.12.2019).

Korczak, J. (1919). Jak kochać dziecko. Dziecko w rodzinie. Warszawa - Kraków: Towarzystwo Wydawnicze w Warszawie.

Korczak, J. (1920). Jak kochać dzieci. Dziecko w rodzinie. Warszawa - Kraków: Towarzystwo Wydawnicze w Warszawie.

Korczak, J. (1929). Jak kochać dziecko. Dziecko w rodzinie. Wyd. II. Warszawa - Kraków: Wydawnictwo Mortkowicza. Towarzystwo Wydawnicze w Warszawie.

Marcela, M. (2020). Jak nie spieprzyć życia swojemu dziecku. Wszystko, co możesz zrobić, żeby edukacja miała sens. Warszawa: Muza.

Sieradzka-Baziur, B. (2018). The evolution of scientific language of pedagogy on the example of Książki o wychowaniu dzieci [Books on children's upbringing] written by Erasmus Gliczner in the context of contemporary determinants of the language of science. The Journal of History of Education, 3-4, 5-16.

Sieradzka-Baziur, B. (2019a). Podmiotowość nadawcy w dawnym tekście naukowym na podstawie analizy manifestu pedagogicznego Janusza Korczaka „Jak kochać dziecko. Dziecko w rodzinie”. Annales Universitatis Paedagogicae Cracoviensis FOLIA 283, Studia Linguistica 14, 203-217. 
Sieradzka-Baziur, B. (2019b). Kształtowanie się języka naukowego pedagogiki na przykładzie manifestu pedagogicznego „Jak kochać dziecko. Dziecko w rodzinie” Janusza Korczaka. Przegląd Historyczno-Oświatowy, nr 3-4, 46-62.

\section{Copyright and License}

This article is published under the terms of the Creative Commons Attribution - NoDerivs (CC BY- ND 4.0) License http://creativecommons.org/licenses/by-nd/4.0/ 